\title{
Variasi bahan baku dan metode pembuatan nori tiruan: kajian pustaka
}

\section{(The variation of raw materials and methods of artificial nori production: areview)}

\author{
Angela Wulansari ${ }^{*}$, Rovina Andriani ${ }^{2}$, Eka Kusuma Dewi ${ }^{3}$ \\ ${ }^{1 *}$ Program Studi Teknologi Hasil Pertanian, Fakultas Pertanian, Universitas Khairun \\ ${ }^{2}$ Program Studi Budidaya Perairan, Fakultas Perikanan dan Kelautan, Universitas Khairun \\ ${ }^{3}$ Program Studi Agribisnis, Fakultas Pertanian, Universitas Khairun \\ E-mail : angela.wulansari223@gmail.com
}

Diterima: 29 Februari 2020; Disetujui: 29 Mei 2020

\begin{abstract}
ABSTRAK
Nori merupakan salah satu produk olahan rumput laut yang banyak dikonsumsi masyarakat dunia.Nori dibuat dengan mengeringkan rumput laut jenis Porphyra. Porphyra tidak banyak ditemukan di Indonesia, tetapi banyak jenis rumput laut lain di Indonesia yang berpotensi menggantikan Porphyra sebagai bahan baku nori tiruan. Daun tumbuhan hijau juga berpotensi menjadi bahan baku nori tiruan. Bahan baku yang berbeda menyebabkan adanya perbedaan cara pembuatan nori tiruan. Kajian pustaka ini membahas jenis-jenis rumput laut dan daun tumbuh-tumbuhan yang dapat digunakan sebagai bahan baku nori tiruan serta metode pembuatan nori tiruan.
\end{abstract}

Kata kunci: nori tiruan, rumput laut, metode pengeringan

\section{ABSTRACT}

Nori or dried seaweed is one of edible product based on seaweed. Nori is well known in the world as one of important ingredient for Japanese and Korean foods. Nori is made from dried Porphyra. Porphyra is hard to be found in Indonesia, but there are many other kind of seaweeds that potentially become the substitution of Porphyra. Artificial nori can be made from another kind of seaweeds and also green leaves as non-seaweed raw material. Different kind of raw materials induced the alteration of method of artificial nori production. This review is discussed about different kind of seaweeds and non-seaweeds as raw materials and the method of artificial nori production.

Keywords: artificial nori, dried seaweed, seaweed drying technology

\section{Pendahuluan}

Rumput laut mengandung komponen bioaktif seperti polisakarida, peptida dan asam amino, poly unsaturated fatty acids (PUFA), sterol, pigmen (klorofil, karotenoid, phycobiliproteins), iodine, serta fenol dan phorotannins (Holdt dan Kraan, 2011). Rumput laut juga memiliki kandungan mineral seperti natrium, kalium, kalsium, magnesium, zat besi, dan zink (Ruperez, 2002).Komponen bioaktif pada rumput laut memberikan efek kesehatan apabila dikonsumsi.Rumput laut dapat mencegah terjadinya penyakit jantung, membantu mengatasi sindrom metabolik, obesitas, diabetes melitus, 
menjaga kesehatan saluran pencernaan, tulang, dan mencegah kanker serta infeksi virus (Brown et al., 2014).

Rumput laut telah diolah menjadi berbagai macam produk, diantaranya adalah sebagai produk pangan, obat-obatan, kosmetik, bahan bakar, dan pupuk.Negara yang penduduknya paling banyak mengkonsumsi rumput laut adalah Jepang, Korea, dan Cina.Produk pangan berbasis rumput laut diantaranya adalah konbu, wakame, hijiki, nori, seaweed pickle, selai rumput laut dan jelly (Kaliaperumal, 2003; Dawczynski, 2007).Rumput laut juga dimanfaatkan oleh industri pangan sebagai sumber hidrokoloid seperti agar, karagenan, dan alginat (Rhein-Knudsen et al., 2015).

Nori merupakan salah satu produk makanan dari rumput laut yang mendunia.Nori banyak digunakan dalam pembuatan makanan Jepang seperti sushi dan onigiri. Nori mengandung 37\% karbohidrat, 2,8\% lemak, 33,2\% protein, $1602 \mathrm{mg} / 100 \mathrm{~g}$ potasium, 728,2 mg/100 g sodium, 720,2 mg/100 g fosfor, 359,2 mg/100 g kalsium, 9,73 mg/100 $\mathrm{g}$ vitamin C, 9,3 mg/100 g vitamin E, 23,830 IU/ $\mathrm{kg}$ vitamin A, dan 2,90 $\mu \mathrm{g} / 100 \mathrm{~g}$ vitamin B12 (Taboada et al., 2012). Kandungan serat pangan pada nori sebesar 33,5048,02\% (Cherry et al., 2019). Komponen serat pangan pada nori didominasi oleh serat larut (soluble fiber).Serat pangan pada nori adalah jenis fukoidan dan alginat yang memiliki efek sebagai antioksidan apabila dikonsumsi (Kuda et al., 2005).

Beberapa penelitian menunjukkan nori dapat memberikan efek baik pada kesehatan. Penelitian oleh Takenaka et al. (2001) menunjukkan tikus yang mengalami defisiensi vitamin B12 dapat meningkat kadar vitamin B12 setelah diberi makanan yang dicampur nori. Pemberian nori pada tikus hiperkolesterolemia dapat menurunkan kadar kolesterol plasma (Bocanegra et al., 2006) dan menurunkan derajat lipid vakuolisasi di hepatosit (Bocanegra et al., 2008). Nori memiliki kandungan porphyran yang memiliki aktivitas antioksidan.Porphyran dapat meningkatkan aktivitas menangkap anion superoksida dan radikal hidroksil, serta menghambat produksi nitrit oksida (Isaka et al., 2015).

Nori pada umumnya dibuat dari rumput laut jenis Porphyra.Nori dibuat dengan mengeringkan Porphyra hingga membentuk lembaran (Kaliaperumal, 2003).Porphyra adalah jenis alga merah yang hidup di daerah beriklim sedang dan subtropis (Lobban dan Harrison, 2000). Porphyra tidak banyak ditemukan di Indonesia, sedangkan permintaan akan nori di Indonesia terus meningkat. Indonesia mengimport nori dari Jepang, Korea, Cina, dan Amerika Serikat untuk memenuhi kebutuhan pasar. Nori dapat dibuat dari rumput laut jenis lain dengan beberapa modifikasi cara membuat. Indonesia kaya akan berbagai jenis rumput laut yang berpotensi untuk menggantikan Porphyra sebagai bahan dasar pembuatan nori. Selain itu, terdapat beberapa jenis tumbuhan yang berpotensi menjadi bahan dasar nori tiruan.Studi pustaka ini membahas tentang penelitian-penelitian pembuatan nori tiruan dari berbagai jenis rumput laut dan tumbuhan yang banyak ditemukan di Indonesia, serta variasi metode pembuatan nori tiruan. 


\section{Alternatif jenis rumput laut sebagai bahan baku nori tiruan}

Bahan baku dalam pembuatan nori adalah rumput laut merah jenis Porphyra. Porphyra hidup pada daerah beriklim sedang dan subtropis.Porphyra umumnya hidup di daerah air surut, intertidal rendah, dan daerah subtidal (Venkatraman dan Mehta, 2018).Porphyra dapat dipanen pertama pada umur 45 hari setelah penanaman.Panen selanjutnya dapat dilakukan pada umur 10-20 hari setelah panen pertama.Nori dibuat dengan mengeringkan Porphyra yang sudah dipotong kecil, membentuk lembaran kotak berukuran kira-kira $10 \times 20 \mathrm{~cm}$ dengan berat $3 \mathrm{~g}$ (Baweja, 2016).Porphyra dapat tumbuh baik pada suhu $10-20^{\circ}$ C.Hal ini yang menyebabkan Porphyra tidak banyak ditemukan di Indonesia. Walaupun demikian, banyak jenis rumput laut lain yang dapat ditemukan dengan mudah di Indonesia. Beberapa rumput laut tersebut berpotensi menjadi bahan baku pembuatan nori tiruan.Beberapa penelitian telah dilakukan untuk membuat nori tiruan dari jenis rumput lain selain Porphyra. Jenis rumput laut lain yang dapat digunakan untuk menggantikan Porphyra dalam produk nori tiruan diantaranya adalah rumput laut Gracillaria gigas (Pamungkas et al., 2019), Hypnea saidana (Lalopua, 2018), dan Eucheuma cottoni (Priatni dan Fauziani, 2015). Beberapa penelitian menggunakan dua jenis rumput laut dalam pembuatan nori tiruan, diantaranya penelitian oleh Zakatia et al. (2017) yang menggunakan Ulva lactuca dan Eucheuma cottoni, penelitian Kurniawan dan Bintoro (2019) menggunakan Ulva lactuca dan Gracillaria sp., penelitian Faris et al. (2019) menggunakan Sargassum sp. dan Eucheuma spinosum, penelitian Erniati et al. (2018) menggunakan Ulva lactuca dan Gelidium sp., serta penelitian Abdulah et al. (2019) menggunakan Gelidium sp. dan Eucheuma cottoni.

Rumput laut yang digunakan untuk mensubstitusi Porphyra sebagian besar berasal dari jenis rumput laut yang sama dengan Porphyra, yaitu rumput laut merah. Gracillaria sp., Hypnea saidana, Eucheuma cottoni, Gelidium sp., dan Eucheuma spinosum merupakan jenis rumput laut merah. Jenis rumput laut lain yang digunakan adalah jenis rumput laut coklat seperti Sargassum sp. dan jenis rumput laut hijau seperti Ulva lactuca. Proses pembuatan nori tiruan dari rumput laut jenis lain berbeda dengan nori dari Porphyra. Banyak permasalahan yang harus dipecahkan untuk membuat nori tiruan yang kualitasnya mendekati nori Porphyra.Hal ini disebabkan oleh karakteristik yang berbeda dari masing-masing jenis rumput laut.

Kekuatan gel dari masing-masing rumput laut akan mempengaruhi tekstur nori yang dihasilkan. Apabila gel yang dihasilkan tidak banyak, maka serat rumput laut tidak akan menyatu, sehingga nori yang dihasilkan akan pecah-pecah dan tidak bisa berbentuk lembaran. Abdulah et al. (2019) melaporkan percobaan awal menggunakan rumput laut Geledium sp. saja tidak berhasil membentuk lembaran nori, karena serat yang tidak menyatu.Eucheuma cottoni ditambahkan pada penelitian ini sebagai binder karena kandungan karagenan yang tinggi.

Warna merupakan salah satu faktor penting dalam pembuatan nori tiruan. Sebagian besar rumput laut yang berpotensi untuk dijadikan bahan baku pembuatan nori tidak memiliki warna kehijauan seperti Porphyra, sehingga perlu dilakukan penambahan 
bahan lain untuk mendapatkan warna yang mirip dengan nori Porphyra. Ulva lactucamemiliki warna natural hijau dan sering dikombinasikan dengan rumput laut jenis lain untuk membuat nori tiruan. Rumput laut jenis lain yang telah dicoba dikombinasikan dengan Ulva lactuca adalah Eucheuma cottoni (Zakatia et al., 2017), Gracillaria sp. (Kurniawan dan Bintoro, 2019), dan Gelidium sp. (Sinulingga, 2019).

Bahan lain yang bukan rumput laut juga ditambahkan pada beberapa penelitian untuk mendapatkan warna hijau seperti pada nori Porphyra. Bahan yang digunakan sebagian besar adalah daun-daun berwarna hijau.Pamungkas et al. (2019) menambahkan daun kenikir (Cosmos caudatus) pada nori tiruan berbasis rumput laut Gracillaria gigas. Warna hijau yang dihasilkan dari penambahan daun kenikir pada penelitian ini belum signifikan mendekati warna hijau dari nori komersial. Bahan lain yang digunakan pada beberapa penelitian untuk memberi warna hijau adalah kulit melinjo hijau (Gunawan, 2019), daun black mulberry (Kahayanis, 2019), daun singkong (Subeki et al., 2018), daun suji (Sari et al., 2019), daun kelor (Pade dan Bulotio, 2019), dan bayam (Fauzan, 2018). Penambahan bahan lain yang memiliki warna natural hijau dapat memperbaiki kualitas organoleptik warna dari nori tiruan. Peningkatan kualitas organoleptik akan meningkatkan tingkat kesukaan dari konsumen terhadap nori tiruan.

\section{Nori tiruan berbahan dasar non-rumput laut}

Tumbuh-tumbuhan, terutama tumbuhan hijau berpotensi menjadi bahan alternatif pembuatan nori. Daun tumbuhan hijau dan rumput laut sama-sama memiliki kandungan serat yang tinggi. Daun dari tumbuhan hijau juga memiliki klorofil yang dapat menjadi pewarna hijau alami. Beberapa penelitian mencoba membuat nori tiruan dari berbagai jenis daun tumbuhan hijau.

Tumbuhan hijau yang digunakan sebagai bahan baku pembuatan nori tiruan diantaranya adalah bayam (Agusta et al., 2017), daun kolesom (Seftiono dan Puspitasari, 2019), daun kelor (Iqbal at al., 2017; Isnaini, 2018), daun cincau hijau pohon (Nurzaman, 2017), dan daun kangkung (Stevani et al., 2019). Selain memiliki warna natural hijau, kelebihan dari penggunaan daun tumbuhan hijau adalah adanya kandungan fenol yang merupakan antioksidan. Nilai total fenol bayam adalah 1,41 mg GAE/g, daun kangkung 0,94 mg GAE/g, dan daun kelor 1,2 mg GAE/g (Novita et al., 2016). Sedangkan total fenol daun cincau hijau adalah 78,32 mg GAE/100 g (Khoiriyah dan Amalia, 2014) dan daun kolesom adalah 0,288-0,456 mg GAE/g (Anyasor et al., 2010). Fenol berperan sebagai antioksidan dengan memberikan atom $\mathrm{H}$ dari grup $\mathrm{OH}$ miliknya pada ikatan radikal -ROO untuk mencegah senyawa tersebut menjadi radikal (Foti, 2007). 
Tabel 1. Macam-macam bahan baku nori tiruan

\begin{tabular}{|c|c|c|}
\hline \multicolumn{3}{|c|}{ Nori Berbahan Dasar Rumput Laut } \\
\hline Bahan Utama & Bahan Tambahan & Sumber \\
\hline Ulva lactucadanGelidium sp. & - & Erniati et al., 2018 \\
\hline Eucheuma cottonii & $\begin{array}{l}\text { Bayam (Amaranthus } \\
\text { hybridus L.) }\end{array}$ & Fauzan, 2018 \\
\hline Gracilaria spp. & $\begin{array}{l}\text { Daun Kelor (Moringa } \\
\text { oleifera) }\end{array}$ & Pade dan Bulotio, 2019 \\
\hline Gracilaria sp. & $\begin{array}{l}\text { Kolang-kaling (Arenga } \\
\text { pinnata (Wurmb) Merr.) } \\
\text { Daun Suji (Pleomele } \\
\text { angustifolia (Medik.) } \\
\text { N.E.Br.) }\end{array}$ & Sari et al., 2019 \\
\hline Eucheuma cottonii & $\begin{array}{l}\text { Daun Singkong (Manihot } \\
\text { esculenta) }\end{array}$ & Subeki et al., 2018 \\
\hline $\begin{array}{l}\text { Gelidium sp.dan Eucheuma } \\
\text { cottonii }\end{array}$ & - & Abdulah et al., 2019 \\
\hline Eucheuma cottonii & $\begin{array}{l}\text { Daun Black Murberry } \\
\text { (Morus nigra L.) }\end{array}$ & Kahayanis, 2019 \\
\hline Eucheuma cottonii & $\begin{array}{l}\text { Kulit Melinjo Hijau } \\
\text { (Gnetum gnemon L.) }\end{array}$ & Gunawan, 2019 \\
\hline Ulva lactucadan Gracilaria sp. & - & $\begin{array}{l}\text { Kurniawan dan Bintoro, } \\
2019\end{array}$ \\
\hline $\begin{array}{l}\text { Sargassum sp.dan Eucheuma } \\
\text { spinosum }\end{array}$ & - & Faris et al., 2019 \\
\hline Eucheuma cottonii & - & Priatni dan Fauziati, 2015 \\
\hline $\begin{array}{l}\text { Ulva lactucadan Eucheuma } \\
\text { cottonii }\end{array}$ & - & Zakaria et al., 2017 \\
\hline Hypnea saidana & - & Lalopua, 2018 \\
\hline Gracilaria gigas & $\begin{array}{l}\text { Daun Kenikir (Cosmos } \\
\text { caudatus) }\end{array}$ & Pamungkas et al., 2019 \\
\hline
\end{tabular}

Nori Berbahan Dasar Non-Rumput Laut

\begin{tabular}{|c|c|c|}
\hline Bahan Utama & Bahan Tambahan & Sumber \\
\hline $\begin{array}{l}\text { Bayam (Amaranthus hybridus } \\
\text { L.) }\end{array}$ & Tepung tapioka & Agusta et al., 2017 \\
\hline Daun Kelor (Moringa oleifera) & $\begin{array}{l}\text { Karagenan } \\
\text { Pati Garut }\end{array}$ & Isnaini, 2018 \\
\hline $\begin{array}{l}\text { Daun Kolesom (Talinum } \\
\text { triangulare (Jacq.) Wild) }\end{array}$ & $\begin{array}{l}\text { Pati Jagung } \\
\text { Pati Kentang } \\
\text { Sagu }\end{array}$ & $\begin{array}{l}\text { Seftiono dan Puspitasari, } \\
2019\end{array}$ \\
\hline $\begin{array}{l}\text { Kangkung (Ipomoea reptans } \\
\text { Poir) }\end{array}$ & Karagenan & Stevani et al., 2019 \\
\hline Daun Kelor (Moringa oleifera) & Karagenan & Iqbal et al., 2017 \\
\hline $\begin{array}{l}\text { Daun Cincau Hijau (Premna } \\
\text { oblongifolia Merr.) }\end{array}$ & - & Nurzaman, 2017 \\
\hline
\end{tabular}


Rumput laut juga mengandung fenol. Daun tumbuhan hijau dapat menggantikan rumput laut dalam pembuatan nori. Nori tiruan dari daun tumbuhan memiliki kualitas mirip dengan nori rumput laut secara fisik maupun kimia.Kelemahan dari daun tumbuhan hijau adalah sebagian besar daun tumbuhan hijau tidak menghasilkan gel yang dibutuhkan sebagai pengikat agar nori tiruan dapat membentuk lembaran dan bertekstur.Bahan pembuat gel yang banyak ditambahkan pada nori tiruan berbahan dasar non-rumput laut adalah karagenan.Stevani et al. (2019) menggunakan beberapa konsentrasi karagenan dalam pembuatan nori tiruan berbahan dasar kangkung.Iqbal et al (2017) juga menggunakan berbagai konsentrasi karagenan dalam pembuatan nori tiruan berbahan dasar daun kelor.Kedua penelitian tersebut melaporkan bahwa nori tiruan terbaik adalah nori yang ditambahkan $1 \%$ karagenan.

Karagenan merupakan grup polisakarida yaitu sulfated galactans (SGs) yang diekstrak dari rumput laut merah (Therkelsen, 1993). Karagenan terdiri dari 3 jenis yaitu $\mathrm{K}$ - karagenan, $\mathbf{t - k a r a g e n a n , ~ d a n ~} \lambda$-karagenan. Karagenan yang larut dalam air akan membentuk thermoreversible gel. $\mathrm{K}$ - karagenan dan $\mathrm{t}$-karagenan akan membentuk gel yang kuat, sedangkan $\lambda$-karagenan tidak akan membentuk gel (Thanh et al., 2002). Karagenan akan mengikat air dan memerangkapnya dalam matriks membentuk gel. Penambahan karagenan pada pembuatan nori tiruan dari bahan baku non-rumput laut, akan membantu mengikat serat agar tidak mudah pecah setelah proses pengeringan dan memberi tekstur pada nori tiruan.

Alternatif bahan pengikat yang digunakan selain karagenan adalah pati.Beberapa jenis pati yang digunakan adalah pati jagung dan pati kentang (Seftiono dan Puspitasari, 2019). Tepung tapioka, tepung beras (Agusta et al., 2017), dan sagu (Seftiono dan Puspitasari, 2019) juga dapat digunakan untuk menggantikan karagenan.Penelitian oleh Isnaini (2018) mengkombinasikan karagenan dan pati garut dalam pembuatan nori tiruan berbahan dasar daun kelor.Selain sebagai bahan pengikat, pati juga dapat memberikan tekstur yang renyah pada nori tiruan.

\section{Metode pembuatan nori tiruan}

Nori Porphyra secara tradisional dibuat dengan mengeringkan rumput laut Phorpyra dibawah sinar matahari hingga membentuk lembaran nori.Rumput laut Phorpyra dipotong-potong dan dicampur dengan air, kemudian dicetak diatas cetakan bambu dan dikeringkan (Kaliaperumal, 2003). Nori secara modern dibuat dengan cara memotong-motong rumput laut, pengepresan rumput laut, kemudian dikeringkan pada suhu $40^{\circ} \mathrm{C}$ selama 3 jam menggunakan mesin pembuat nori otomatis. Nori kemudian dikeringkan kembali pada suhu $70^{\circ} \mathrm{C}$ selama 3 jam.Nori yang telah kering kemudian dikelompokkan menjadi beberapa golongan yaitu, kelas 1, kelas 2, kelas 3, kelas 4, dan diluar kelas.Produk nori panggang dibuat dengan memanggang nori pada suhu $300^{\circ}$ Cselama 3 detik (Masuda et al., 2015). Proses pembuatan nori tiruan berbeda dengan nori komersil. Perbedaan pembuatan nori tiruan didasari oleh jenis bahan baku yang digunakan. 
Beberapa penelitian pembuatan nori tiruan masih menggunakan metode tradisional.Pengeringan nori dilakukan dengan mengandalkan sinar matahari. Nori dari rumput laut Hypnea saidana dibuat dengan cara mengeringkan rumput laut yang telah dipanaskan dibawah sinar matahari (Lalopua, 2018). Pade dan Bulotio (2019) membuat nori tiruan dari campuran rumput laut Gracillaria spp dan daun kelor dengan menggabungkan dua metode pengeringan.Pengeringan awal dilakukan dengan mengandalkan sinar matahari, kemudian setelah nori kering, dilakukan pengeringan kembali menggunakan oven pada suhu $75^{\circ} \mathrm{C}$ selama 2 menit.Ada pula yang mengeringkan rumput laut di suhu ruang. Nori tiruan dari Eucheuma cottonii dikeringkan pada suhu kamar selama 24 jam (Priatni dan Fauziati, 2015). Subeki et al. (2018) membuat nori tiruan dari Eucheuma cottoni dan daun singkong dengan mengeringkan adonan nori pada suhu kamar selama 3 hari, kemudian dikeringkan kembali menggunakan oven suhu $60^{\circ} \mathrm{C}$ selama 10 menit.

Selain menggunakan metode tradisional, nori tiruan juga dibuat dengan menggunakan berbagai macam mesin pengering.Mesin pengering yang digunakan adalah oven, cabinet dryer, dan dehydrator.Suhu yang digunakan bervariasi. Suhu yang digunakan beberapa peneliti untuk mengeringkan nori tiruan menggunakan oven adalah 50-70 ${ }^{\circ} \mathrm{C}$ dengan lama waktu pengeringan 2-15 jam (Zakaria et al., 2018; Iqbal et al., 2017; Pade dan Bulotio, 2019; Subeki et al., 2018; Abdulah et al., 2019; Kurniawan dan Bintoro, 2019; Faris et al., 2019). Suhu cabinet dryer yang digunakan untuk mengeringkan nori tiruan adalah $45-60^{\circ} \mathrm{C}$ dengan lama waktu pengeringan 3-16 jam (Stevani et al., 2019; Sari et al., 2019; Zakaria et al., 2017; Pamungkas et al., 2019), sedangkan suhu dehydrator yang digunakan untuk mengeringkan nori tiruan adalah $50^{\circ} \mathrm{C}$ dengan lama pengeringan 8 jam (Seftiono dan Puspitasari, 2019). Waktu yang dibutuhkan untuk mengeringkan nori tiruan bervariasi. Variasi waktu pengeringan nori tiruan diduga berkaitan dengan jenis mesin pengering, suhu pengeringan, ketebalan nori tiruan, dan bahan baku.

Rasa merupakan salah satu komponen yang penting dalam pembuatan nori tiruan. Nori tiruan diharapkan memiliki rasa yang sama dengan nori komersial (Porphyra). Bumbu-bumbu yang ditambahkan pada adonan nori adalah garam, gula, bawang putih, minyak wijen, saus teriyaki, olive oil, saus ikan, dan lada (Abdulah et al., 2019; Pade dan Bulotio, 2019).Tidak semua bumbu diatas ditambahkan pada adonan nori tiruan.Sebagian besar nori tiruan hanya ditambahkan garam, bawang putih, dan minyak wijen.Penambahan bumbu-bumbu tersebut untuk memberikan rasa gurih dan asin seperti pada nori komersial.Minyak wijen selain memberikan rasa gurih, juga memberikan aroma khas seperti nori komersial.

Proses pembuatan nori tiruan berbeda dengan nori Porphyra. Rumput laut atau bahan non-rumput laut dihaluskan terlebih dahulu menggunakan blender kemudian dipanaskan sampai mendidih.Adonan kemudian ditambah dengan bumbu-bumbu dan dimasukkan ke dalam cetakan untuk dikeringkan (Pamungkan et al., 2019; Stevani et al., 2019). Perbedaan proses pembuatan nori Porphyra dengan nori tiruan adalah rumput laut Porphyra tidak perlu melalui proses penghancuran dengan blender terlebih 
dahulu, tetapi hanya dilakukan pemotongan kemudian dijemur, Nori Porphyra juga tidak melewati proses pemanasan terlebih dahulu. Nori tiruan berbahan dasar rumput laut jenis lain memerlukan proses pemanasan untuk mengeluarkan gel. Nori tiruan berbahan dasar non-rumput laut juga memerlukan proses pemanasan untuk mengeluarkan gel dari bahan isian (karagenan, pati, atau tepung) yang digunakan sebagai pengganti rumput laut. Gel diperlukan untuk menyatukan serat bahan sehingga nori tiruan dapat membentuk lembaran yang utuh dan untuk memberikan tekstur pada nori tiruan.

\section{Kesimpulan}

Nori dapat dibuat dari rumput laut jenis lain yang banyak ditemukan di Indonesia untuk menggantikan Porphyra. Warna hijau pada nori dapat diciptakan dengan mengkombinasikan beberapa jenis rumput laut yang memiliki warna alami hijau, atau dengan menambahkan bahan lain yang memiliki warna alami hijau seperti daun tumbuh-tumbuhan atau kulit buah. Selain berbahan dasar rumput laut, nori tiruan dapat dibuat menggunakan daun tumbuh-tumbuhan.Nori tiruan berbahan dasar daun tumbuhtumbuhan perlu ditambahkan bahan pengisi sebagai pengikat.Bahan pengisi bisa berupa karagenan, pati, atau tepung-tepungan. Pengeringan nori tiruan dapat dilakukan dengan cara tradisional yaitu mengandalkan sinar matahari atau menggunakan alat pengering seperti oven, cabinet dryer, dan dehydrator. Nori tiruan dengan kualitas yang hampir sama dengan nori komersial dapat membantu mengurangi import nori Indonesia dan dapat menjadi alternatif diversifikasi produk pangan berbahan dasar rumput laut.

\section{Daftar Pustaka}

Agusta, E.N., Amalia, L., Hutami, R. 2017. Formulasi Nori Artifisial Berbahan Baku Bayam (Amaranthus hybridus L.). Jurnal Agroindustri Halal. 3(1): 19-27

Anyasor, G.R., Ogunwenmo, K.O., Ogunnowo, A.A., Alao-Sanni, O. 2010.Comparative Antioxidant, Phytochemical, and Proximate Analysis of Aqueous and Methanolic Extracts of Vernonia amygdalina and Talinum triangulare.Pakistan Journal of Nutrition. 9(3): 259-264

Baweja, P. 2016. Seaweed in Health and Disease Prevention.In Biology of Seaweed. (Academic Press, United States)

Bocanegra, A., Benedi, J., Sanches-Muniz, F.J. 2006. Differential Effect of Konbu and Nori Seaweed Dietary Supplementation on Liver Glutathione Status in Normoand Hypercholesterolemic Growing Rats. British Journal of Nutrition. 95(4): 696-702

Bocanegra, A., Nieto, A., Bastida, S., Benedi, J., Sanches-Muniz, F.J. 2008. A Nori but not a Konbu Dietary Supplement Decreases The Cholesterolemia, Liver Fat Infiltration and Mineral Bioavailability in Hypercholesterolemic Growing Wistar Rats. British Journal of Nutrition. 99(2): 272-280

Brown, E.M., Allsopp, P.J., Magee, P.J., Gill, C.I.R., Nitecki, S.,Strain, C.R., McSorley, E.M. 2014.Seaweed and Human Health.Nutrition Reviews. 72(3):205-216 
Cherry, P., O’Hara, C., Magee, P.J., McSorley, E.M., Allsopp, P.J. 2019.Risks and Benefits of Consuming Edible Seaweeds.Nutrition Reviews. 77(5):307-329

Dawczynski, C., Schubert, R., Jahreis, G. 2007. Amino Acids, Fatty Acids, and Dietary Fiber in Edible Seaweed Products.Food Chemistry. 103: 891-899

Erniati, Zakaria, F.R., Prangdimurti, E., Adawiyah, D.R., Priosoeryanto, B.P., Huda, N. 2018. Chemical Evaluation of a Nori-Like Product (Geluring) Made from The Mixture of Gelidium sp. and Ulva lactuca Seaweeds.Nutrition Food Science Journal. 6(3): 664-671

Faris, A., Liviawaty, E., Andriani, Y., Affrianto, E. 2019. Nori Level of Preference with Mixed Sargassum sp. and Eucheuma spinosum Seaweed as Raw Materials. Asian Food Science Journal. 11(2): 1-9

Fauzan, M.A. 2018. Kajian Pembuatan Nori Bar dari Berbagai Varietas Rumput Laut (Eucheuma cottonii) dengan Penambahan Bayam (Amaranthus hybridus L.).Skripsi. Fakultas Pertanian-Peternakan, Ilmu dan Teknologi Pangan, Universitas Muhammadiyah Malang

Foti, M.C. 2007. Antioxidant Properties of Phenols.Journal of Pharmacy and Pharmacology. 59(12): 1673-1685

Gunawan, H.C. 2019. Pengaruh Perbandingan Rumput Laut (Eucheuma cottonii) dengan Kulit Melinjo Hijau (Gnetum gnemon L.) dan Konsentrasi Karagenan Pada Nori.Skripsi. Fakultas Teknik, Teknik Pangan, Universitas Pasundan

Holdt, S.L., Kraan, S. 2011. Bioactive Compounds in Seaweed: Fuctional Food Application and Legislation. J Apply Phyco. 23: 543-597

Iqbal, M., Wahyuni, S., Syukri, M. 2017.Pengaruh Konsentrasi k-Karagenan Terhadap Nilai Organoleptik Produk Vegetable Leather dari Daun Kelor (Moringa oleifera L.).Jurnal Sains dan Teknologi Pangan. 2(3): 641-647

Isaka, S., Cho, K., Nakazono, S., Abu, R., Ueno, M., Kim, D., Oda, T. 2015. Antioxidant and Anti-inflammatory Activities of Porphyran Isolated from Discolored Nori (Porphyra yezoensis).International Journal of Biologycal Macromolecules. 74: 68-75

Isnaini, S.F. 2018.Karakteristik Nori Daun Kelor dengan Penambahan Karagenan dan Pati Garut Sebagai Bahan Pembentuk Gel.Skripsi. Fakultas Teknologi Pertanian, Teknologi Hasil Pertanian, Universitas Jember

Kahayanis, N. 2019.Pengaruh Perbandingan Bubur Rumput Laut (Eucheuma cottonii) dengan Bubur Daun Black Mulberry (Morus nigra L.)Terhadap Karakteristik Nori Analog.Skripsi. Fakultas Teknik, Teknik Pangan, Universitas Pasundan

Kaliaperumal,N.2003. Products From Seaweeds. SDMRI Research Publication.3:33-42 Khoiriyah, N., Amalia, L. 2014. Formulasi Cincau Jelly Drink (Premna oblongifolia L. Merr) Sebagai Pangan Fungsional Sumber Antioksidan.Jurnal Gizi dan Pangan. 9(2): 73-80

Kuda, T., Tsunekawa, M., Hishi, T., Araki, Y. 2005. Antioxidant Properties of Dried Kayamo-Nori, a Brown Alga Scytosiphon lomentaria (Scytosiphonales, Phaeophyceae). Food Chemistry. 89(4): 617-622 
Kurniawan, K., Bintoro, N. 2019. Engineering Analysis in Manufacturing Process of Nori Made from Mixture of Ulva .lactuca and Gracillaria sp. IOP Conference Series: Earth and Environment Science. 355012036

Lalopua, V.M. 2018.Karakteristik Fisika Kimia Nori Rumput Laut Merah Hypnea saidana Menggunakan Metode Pembuatan Berbeda dengan Penjemuran Matahari.Majalah BIAM. 14(01): 28-36

Lobban, C.S., Harrison, P.J. 2000.Seaweed Ecology and Physiology. Cambridge: The Press Syndicate of The University of Cambridge

Masuda, T., Yamamoto, A., Toyohara, H. 2015.The Iron Content and Ferritin Contribution in Fresh, Dried, and Toasted Nori, Pyropia yeroensis.Bioscience Biotechnology and Biochemistry. 79(1): 74-81

Novita, M., Sulaiman, M.I., Yura, S. 2016. Pengaruh Jenis Pelarut Terhadap Aktifitas Antioksidan dan Kandungan Fenol Beberapa Jenis Bayam dan Sayuran Lain.Jurnal Ilmiah Mahasiswa Pertanian Unsyiah. 1(1): 935-940

Nurzaman, A. 2017.Pengaruh Lama Pengeringan Terhadap Sifat Fisikokimia dan Organoleptik Nori Daun Cincau Hijau Pohon (Premna oblongifoliaMerr.).Skripsi. Fakultas Teknik, Tata Boga, Universitas Negeri Malang

Pade, S.W., Bulotio, N.F. 2019.Nutrifikasi Daun Kelor (Moringa oleifera) dengan Varietas Umur Daun Berbeda Terhadap Karakteristik Mutu Nori Rumput Laut (Gracillaria spp).Journal of Agritech Science. 3(2): 128-133

Pamungkas, P.P., Yuwono, S.S., Fibrianto, K. 2019. Potensi Rumput Laut Merah (Gracillaria gigas) dan Penambahan Daun Kenikir (Cosmos caudatus) Sebagai Bahan Baku Pembuatan Nori.Jurnal Teknologi Pertanian. 20(3): 171-180

Priatni, A.,Fauziati.2015.Karakteristik Sifat Fisik Kimia dan Deskriptif Nori dari Rumput Laut Jenis Eucheuma cottoni.Jurnal Riset Teknologi Industri.9(2):96106

Rhein-Knudsen, N., Ale, M.T., Meyer, A.S. 2015. Seaweed Hydrocolloid Production: An Update on Enzyme Assisted Extraction and Modification Technologies. Marine Drugs. 13: 3340-3359

Ruperez, P.2002. Mineral Content of Edible Marine Seaweeds.Food Chemistry.79:2326

Sari, D.K., Rahardjanto, A., Husamah, Purwanti, E., Permana, T.I., Fauzi, A. 2019. The Formulation of Artificial Nori with The Base Mixture Ingredients of Gracillaria sp. and Arenga pinnata (Wurmb) Merr. Using The Natural Colorant FromPleomele angustifolia (Medik.) N.E.Br. IOP Conference Series: Earth and Environtment Science. 276012013

Seftiono, H., Puspitasari, D. 2019. Analisis Organoleptik dan Kadar Serat Nori Analog Daun Kolesom (Talinum triangulare (Jacq.)Wild).Jurnal Bioindustri. 2(1):385398 
Stevani, N., Mustofa, A., Wulandari, Y.W. 2019.Pengaruh Lama Pengeringan dan Penambahan Karagenan Terhadap Karakteristik Nori Daun Kangkung (Ipomoea reptans Poir).Jurnal JITIPARI. 3: 85-96

Subeki, Asih, I.P., Setyani, S., Nurainy, F. 2018. Kajian Formulasi Daun Singkong (Manihot esculenta) dan Rumput Laut (Eucheuma cottonii) Terhadap Sifat Sensor dan Kimia Nori. Prosiding Seminar Nasional Pengembangan Teknologi Pertanian, Lampung: 8 Oktober 2018. Hal. 357-365

Takenaka, S., Sugiyama, S., Ebara, S., Miyamoto, E., Abe, K., Tamura, Y., Watanabe, F., Tsuyama, S., Nakano, Y. 2001.Feeding Dried Purple Laver (nori) to Vitamin B12 Deficient Rats Significantly Improve Vitamin B12 Status.British Journal of Nutrition. 85(6): 699-703.

Thanh, T.T.T., Yuguchi, Y., Mimura, M., Yasunaga, H., Takano, R., Urakawa, H., Kajiwara, K. 2002. Molecular Characteristics and Gelling Properties of The Carrageenan Family, 1. Preparation of Novel Carrageenan and Their Dilute Solution Properties.Macromolecular Chemistry and Physics. 203(1): 15-23

Therkelsen, G.H. 1993. Carrageenan.In Industrial Gums (Third Ed.). (Academic Press, United States)

Venkatraman, K.L., Mehta, A. 2019. Health Benefit and Pharmacological Effects of Porphyra Species.Plants Food for Human Nutrition. 74: 10-17

Zakaria, F.R., Priosoeryanto, B.P., Erniati, Sajida. 2017. Karakteristik Nori dariCampuran Rumput Laut Ulva lactuca dan Eucheuma cottoni.JPB Kelautandan Perikanan. 12(1): 23-30. 